KRISTA KODRES

\title{
TOWARD A NEW CONCEPT OF PROGRESSIVE ART: ART HISTORY IN THE SERVICE OF MODERNISATION IN THE LATE SOCIALIST PERIOD. AN ESTONIAN CASE
}

I should begin by recalling a well-known incident from the Khrushchev Thaw period in Soviet history, because of its remarkable illuminating capacity: it reveals a paradox description of a cultural era when certain ideas and things were simultaneously allowed and prohibited ${ }^{1}$. This event took place in 1962. A scandal erupted in the central Moscow exhibition space, the Manege. Artworks that demonstrated movement away from the Stalinist artistic doctrine of Socialist Realism to Modernism were on display; these were works by artists who had not been exhibited in the USSR for decades. The main protagonist of the Manege exhibition, however, was a VIP, Nikita Khrushchev himself, whose visit ended with him shouting at the modern art idiom and lambasting modernist formalists as "pederasts". ${ }^{2}$ But there was nothing to be done; Khrushchev himself had, in the mid-1950s, opened the door to the modern world and he was no longer able to close it entirely. He might have been disappointed, but the Thaw was already in action.

My paper deals with one of the fields of renewal back then - socialist art history, which, according to the Soviet understanding, comprised part of the "ideological field" ${ }^{3}$. I will discuss the modernisation of art history based on the example of the Estonian Soviet Socialist Republic (Estonian SSR), where art historians were forced to accept the Soviets' centrally constructed Marxist-Len-

1 The research for this article was supported by the state research grant of the Estonian Republic "Historicizing art: Knowledge production in art history in Estonia amidst changing ideologies and disciplinary developments" (PUT788; 1.01.2015-31.12.2018).

2 M. Bernstein, Vana kaev. Mälestusteraamat [Old Well. Book of Memoires], Tartu 2009, pp. 242-244.

3 А. Штамбок, "Против идеалистического исктолкования развития искусства" [A. Shtambok, Protiv idealistitsheskovo istolkovanija razvitija iskusstva / Against the idealistic interpretation of the development of art], Искусство [Iskusstvo] 1950, 5, p. 56. 
inist aesthetic and approach to art and art history. The promising post-Stalinist rhetoric encouraged public discussion on the theoretical fundamentals of art and art history in Moscow and Leningrad art history circles in particular, centering on discussion of the nature and boundaries of Realism. ${ }^{4}$ As a result, Soviet art historians fell into two camps in interpreting Realism: the dogmatic and revisionist, and the latter was embraced in Estonia. In the following, I will delineate criticism of the Stalinist art history canon in the late 1950s and early 1960s, pointing out the key positions in regard to the changes in the discourse, and examining how they were expressed in the rewriting of art history, based on the Estonian example. It should be noted here that the art history revisionism in both the USSR and the Estonian SSR was not characterised by radicalism. On the contrary, it involved rather cautious criticism. Memories of the Stalinist terror had not faded, thus, art history texts of the era are cryptic and camouflaged, with the progressive parts concealed in an otherwise orthodox flood of rhetoric. The ambivalence that is evident in the texts leads us to the problems of the ideological engagement of the interpretation of art and its history, which both supported and undermined the political regime. From the standpoint of discipline, this meant the beginning of the renewal of the socialist art history discourse $^{5}$, which, among other things, had a significant impact on modernisation and the public exhibition of contemporary art. In the art context, the idea of progressiveness began to be reconsidered. In previous discourse, progress was linked with the "realist" artistic method that sprang from a progressive social order. Now, however, revisionist art historians found new arguments for accepting different cultures of form, both historical and contemporary, and often these arguments were "discovered" in Marxism itself.

\section{AN ART PRIMER, 1967}

In 1967, a work was published by the accomplished artist Ott Kangilaski and his nephew, the art historian Jaak Kangilaski (b. 1939): ${ }^{6}$ the Kunsti

${ }^{4}$ B. Bernstein, "Seoses vaidlustega realismi üle" [Regarding the disputes over realism, 1-2], Kunst 1966, 3, pp. 13-22, and 1961, 1, pp. 1-14; J. Kangilaski, "Realismi mõiste metamorfoosid nõukogude kunstiteoorias" [Metamorphoses of the notion of realism in Soviet art theory], Kunstiteaduslikke Uurimusi / Studies on Art and Architecture 2003, 12(1-2), pp. 11-24.

${ }^{5}$ K. Kodres, K. Jõekalda, "Introduction to Socialist Art History: On Formulating the Soviet Canon," in: A Socialist Realist History? Writing Art History in the Post-War Decades, eds. K. Kodres, K. Jõekalda, M. Marek, Köln, Weimar, Wien 2019.

${ }^{6}$ Jaak Kangilaski later became one of the most renowned art historians in Estonia. He defended his candidate thesis (PhD) on the French artist group "Les Nabis" in 1969, su- 
kukeaabits - Basic Art Primer - subtitled "Fundamental Knowledge of Art and Art History." 7 The book, close to 350 pages in length and with a print run of 10,000, explained the principles of art for "anyone interested in art", to facilitate the "true enjoyment of art" ${ }^{1}$. It was also the first art history text published after the war for the Estonian general public and, despite the title, it was a professional treatment of the field of art and its history. The most recent survey book before it, the over 800-page-long "Üldine kunstiajalugu" (General History of Art), had been published in 1937. In 1940, as the Soviet occupation started in Estonia, this book was among the publications hacked to bits during a book destruction campaign, due to its "bourgeois" approach (along with the same author's History of Estonian Art, 1939-40). ${ }^{9}$ During the Soviet era, the remaining public copies of Voldemar Vaga's General History of Art were hidden away in special collections in libraries.

In its 200 pages, Jaak Kangilaski's Primer laid out the art history of the world. The text was chronologically structured, based on the concept of periods known from the discourse of historical materialism: art in pre-historical times, art from the ages of slavery, feudalism, capitalism and imperialism, and finally a chapter on "Soviet art and progressive art in foreign countries": A close reading of the Kangilaski text reveals the main antecedents for the young author's approach. The most important source was The Fundamentals of Marxist-Leninist aesthetics, translated into Estonian in 1961, which had been published in Moscow by the Academy of Sciences of the USSR's Institute of Philosophy, the Art History Institute, the Gorky Institute of World Literature and the research staff of the Soviet Academy of Sciences in 1960; the article "The historic laws of the development of art" was written by Nina Dmitrieva. ${ }^{10}$ Thus, it was a very fresh treatment. Another inspiration for Kangilaski was the German Democratic Republic author Wolfgang Hütt's simi-

pervised by Prof. Vladimir F. Levinson-Lessing, a leading specialist on Western art in State Hermitage Museum in Leningrad. Kangilaski chaired the art history department in Estonian State Academy of Arts between 1978 and 1987, was appointed a rector of the same institution in 1989, and was professor of art history of Tartu University from 1995-2005. Today he is prof. em. of Tartu University.

7 O. Kangilaski, J. Kangilaski, Kunsti kukeaabits. Algteadmisi kunstist ja kunstiajaloost [A Basic Art Primer. Fundamental Knowledge of Art and Art History], Tallinn 1967.

${ }^{8}$ Ibidem, p. 5.

9 O. Esna, "Kuidas puhastati Eesti raamatukogusid" [How the Estonian libraries were expurgated], Pärnu Postimees 2014, 27th February.

10 Основы марксистко-ленинской эстетики [Osnovõ marksistko-leninskoi estetiki], Moscow 1960; in Estonian: Marksistlik-leninliku esteetika alused, Tallinn 1961. 
larly fresh Wir und die Kunst, ${ }_{11}^{11}$ published in 1959, from which the structure of the Primer was largely borrowed. Particularly in regard to characterising the architectural aspects of the various eras, Kangilaski relied on Vaga's General History of Art, which, despite being a "forbidden" book, survived in many home libraries.

\section{MODERNISATION OF DISCOURSE}

As stated, in the following, I will introduce the deviations and shifts in Jaak Kangilaski's approach from the existing socialist art history canon. They were based on a departure from the fundamental theses of past Stalinist discourse. ${ }^{12}$ For example, in providing a theoretical introduction to the general art history, Kangilaski did not write anything about the (Leninist) theory of two cultures, which held that every class-ruled society also had two arts - progressive and reactionary - depending on which class a given work reflected. According to the Marxist-Leninist view of history at that point, each class likewise played a dual role: it was progressive in one phase of historical development, then reactionary in another. In this view, the bourgeois culture that rose to prominence from the Renaissance era was progressive (as it undermined the outdated feudal relations) and so was its art, but the bourgeois culture of the $19^{\text {th }}$ century had become decadent and reactionary, as had its art. While Jaak Kangilaski did mention the concept of progressive and reactionary ("The superstructure reflects the progressive or reactionary nature of the substructure" $\left.{ }^{\prime 13}\right)$, he further elaborated on this, noting the defining element of art was instead the "Zeitgeist," the spirit of the era, which, as he wrote, "does not mean anything mysterious or supernatural but is simply the sum of the social views that objectively existed and exist in each phase of the development of humankind." 14 Thus, he openly united the "hostile classes" of the formations and laid a foundation for the rise of common art characteristics, denoted by the term "style". ${ }^{15}$ As is later evidenced by various passages in the main text, art transforms pursuant to the "will-to-art" (Kunstwollen) characteristic of the entire human society. ${ }^{16}$

${ }^{11}$ W. Hütt, Wir und die Kunst. Eine Einführung in die Kunstbetrachtung und Kunstgeschichte, Berlin 1959.

12 Kodres, Jõekalda, "Introduction to Socialist Art History".

${ }^{13}$ Kangilaski, Primer..., p. 148.

14 Ibidem.

15 Ibidem, p. 149.

${ }^{16}$ Ibidem, pp. 156, 209. 
What also stands apart from earlier writing is the interpretation of the relationship between the Marxist-Leninist substructure (economic relations) and the superstructure (culture). Stalinist art history required proving a correspondence between the two (a distortion of Marxist theory). Jaak Kangilaski, however, stated flatly that: "...art is relatively independent and its development has its internal logic and continuity," adding that "it seems that there is much that is random in art; its development zigzags and fluctuates, but is ultimately inevitable." ${ }^{17}$ At the end of the introduction, Jaak Kangilaski also noted that in general "the value of artworks is constant [in time - K. K.]". However, he argued the contrary elsewhere: "Art history assesses the art of the past from the standpoint of its own era and compares it to previous assessments." ${ }^{18}$ The first half of this sentence is undoubtedly aligned with one of the main goals of Marxist-Leninist art history: the didacticism of art history and its ability to transform the present, which could take place by giving an "objective assessment" to an artwork. These contradictory concepts and assessments are from time to time striking while reading the text of the Primer.

\section{THE PROBLEM OF REALISM AND THE REAPPRAISAL OF ART HISTORY}

Continuing from the ambivalences of the discourse to its applications in the Primer, it becomes evident that the half-blind change in the underlying views was also reflected in approaches to specific epochs in art history, expressed particularly in the general appraisals given to the styles of the periods. It should be recalled, in this light, that alongside historical materialism and the theory of reflection, the Stalinist art and art history theory was, of course, determined by an aesthetic doctrine, the doctrine of Realism. Owing its aesthetic and ideological content mainly to G. Lukacs and M. Lifshits, ${ }^{19}$ Realism was considered in socialist art history to be the only method of depiction that adequately reflected world reality and thus was progressive: a method by which life's truth was manifested through artistic truth. While during the Stalin era Socialist Realist art was defined by relatively specific characteristics of form, the revisionist art historians of the Thaw period re-interpreted art's association with a specific depictive idiom, the mimetic-generalising method of depiction, without rhetorically abandoning the concept of Realism and Socialist Realism.

\footnotetext{
${ }_{17}$ Ibidem, p. 149; „Self-development” is also emphasized on p. 315.

18 Ibidem, p. 121.

19 See e.g.: G. Lukacs, Essays über Realismus, Berlin 1948; М. Аифшиц, Вопрось искусства и философии [M. Lifshits, Voprosõ iskusstva i filosofii], Moscow 1935.
} 
Various humanities disciplines in the USSR, including the Estonian SSR, had raised the question of the boundaries of Realism as early as 1956, and precisely this became the most disputed problem for dogmatists and revisionists. In 1963, the French communist Roger Garaudy's "D'un realisme sans rivages" was published, in which he set forth a thesis of Realism without limits; this discussion merely poured fuel on the fire. ${ }^{20}$ Jaak Kangilaski also chimed in, publishing an article entitled "Disputes in Marxist Aesthetics" in the leading Estonian SSR literary journal Looming (Creation) in $1965 .{ }^{21}$ In it, he quoted the "revisionist" aestheticist Moissei Kagan from Leningrad, who warned against treating art as one-dimensional: only as a reflection, only as an artist's self-expression, or only as a means of reshaping reality. ${ }^{22}$

In the Primer's positions on art periods and artworks, it is significant that Jaak Kangilaski expressed clear support for "Realism without boundaries." ${ }^{23}$ As a specific example, Gothic art - known for its anti-Realist depiction and feudal and religious content - received praise from Kangilaski. He wrote: "Thus, medieval art was very different from ancient Greek art; it was practically its opposite, yet still enriched ... the world with invaluable accomplishments." ${ }^{24}$ In fact, here Kangilaski was rephrasing the opinion of the Moscow art historian Nina Dmitrieva, expressed in Fundamentals of Marxist-Leninist Aesthetics: "Foreign to Gothic Art was that fondness for the beauty of natural and normal forms, the striving for verisimilitude, that is so typical of the art of antiquity" and "...yet the realism of medieval art cannot be denied, as art reflects the real conflicts in reality." ${ }^{25} \mathrm{~A}$ phrase in the Dmitrieva quotation - "expanding the spectrum of feelings encompassed by the term "humanity'" - was a clever rhetorical reference to the Realist tendency in Gothic art. A rather similar idea can be found in the GDR author Wolfgang Hütt's book. ${ }^{26}$

In the canon of Socialist art history, Baroque Art, too, was a disparaged style of art. It was reactionary, because it reflected absolutism and the degen-

${ }^{20}$ Kangilaski, "Realismi mõiste metamorfoosid," pp. 11-28.

${ }^{21}$ J. Kangilaski, "Vaidlustest marksistlikus esteetikas" [Disputes in Marxist aesthetics], Looming 1965, 11, pp. 1707-1718.

22 Ibidem, p. 1717. See also: М. С. Каган, Һекциии по марксистско-ленинской әстетике, чacmo II [M. S. Kagan, Lektsii po marksistsko-leninskoi estetikie], Leningrad 1964, p. 13.

${ }^{23}$ He quotes not Garaudy but a Moscow art historian O. Larmin: "There is an array of independent, Realist-type methods: Renaissance Realism, Age of Enlightenment Realism, $19^{\text {th }}$ century Critical Realism, Socialist Realism. " - О. В. Аармин, Художественный метод и стиль [O. V. Larmin, Hudozhestvennõi metod i stilj], Moscow 1964, p. 69.

${ }^{24}$ Kangilaski, Primer, p. 221.

${ }_{25}$ Marksistlik-leninliku esteetika alused, p. 230.

${ }^{26}$ Hütt, Wir und die Kunst, p. 26. 
erate noble class and distorted Renaissance-style Realism, using an inflated, exaggerated, "empty" artistic idiom pursuant to its content. ${ }^{27}$ Jaak Kangilaski, however, wrote: "Yet Baroque art is no less valuable than [the realistic art of K. K.] Classicism." 28

Using the same interpretative pattern, Kangilaski also considered Impressionistic art, which was deplored in Stalinist art histories, but had been allowed in exhibition halls in the late 1950s due to its "profoundly humanistic content" ${ }^{29}$ Kangilaski had to resort to significantly greater rhetorical manoeuvring, however, in interpreting all of the "bourgeois" art movements of the $20^{\text {th }}$ century, such as Abstractionism, Expressionism and Surrealism, which had for long decades been synonymous with the formalist bourgeois art of the imperialist social formation. He praised the non-Realist Matisse, who, as he said, albeit erroneously, been previously been considered anti-humanist. ${ }^{30}$ Actually, Kangilaski wrote, Matisse's work was "national" [yet another positive banner concept from the canon of Socialist art history - K. K.]. ${ }^{31}$ It also represented a logical continuation of the earlier development of art and owed a great deal to the Realists and Impressionists. ${ }^{32}$

Jaak Kangilaski also imbued Abstractionism with a positive meaning, saying that this mode of depiction "is not some monopoly of deliberately reactionary forces: it is supported by many Western artists and art aficionados with progressive views." ${ }^{33}$ Of course, Kangilaski also praised Picasso (whom Nina Dmitrieva went so far as to lionise ${ }^{34}$ ), who, above all, as a "progressive" persona, had already been more or less rehabilitated in Soviet art history by this time, with an exhibition having taken place in Moscow. ${ }^{35}$ Moreover, Kan-

27 See K. Kodres, "Scientific Baroque - for Everyone. Constructing and Conveying an Art Epoch during the Stalinist Period in the Soviet Union and in Soviet Estonia," in: Baroque for a Wide Public: Popular Media and Their Constructions of the Epoch on Both Sides of the Iron Curtain, eds. M. Marek, E. Pluhařovà-Grigienéenè, Journal of Art Historiography. Special Issue 2016, 15 [https://arthistoriography.wordpress.com/15-dec16/], pp. 1-25.

28 Kangilaski, Primer, p. 240.

${ }^{29}$ Ibidem, p. 276.

30 Ibidem, p. 297.

31 See Väike esteetika leksikon [Small Lexicon of Aesthetics], Tallinn 1965, pp. 184 186; Kodres, Jõekalda, "A Socialist Realist History?"

32 Kangilaski, Primer, p. 296.

33 Ibidem, p. 314.

${ }^{34}$ Основы марксистко-ленинской эстетики [Osnovõ marksistko-leninskoi estetiki], p. 267.

${ }^{35}$ M. Dmitreva, "The Riddle of Modernism in the Art Historical Discourse of the Thaw," in: A Socialist Realist History? Writing Art History in the Post-War Decades, eds. K. Kodres, K. Jõekalda, M. Marek, Köln, Weimar, Wien 2019, pp. 143-169. 
gilaski linked Surrealism ${ }^{36}$ - the bęte noire for Socialist Realist critics of the day $^{37}$ - with Picasso, obviously in order to legitimise the style. To sum up $20^{\text {th }}$-century Western art, Kangilaski again wrote of the internal logic of the development of art, due to which, he said, it was natural that "quite similar means of expression can serve significantly different ideologies ... Thus, the assertions that every non-figurative work taken separately was a direct expression of imperialistic or anti-humanist ideology are not borne out." 38

Summing up, the Basic Art Primer, as well as shorter Estonian art history treatments of the 1960s, used textual strategies that made it possible to forswear the appraisals of Stalinist art history, which, among other things, meant moving toward a revised definition of the progressive in art.

The Small Lexicon of Aesthetics published by the Political Literature Institute in Moscow in 1963, which appeared in Estonian two years later, contains a two-page article under the title "Progress in art." ${ }^{39}$ It defines the essence of the term as follows: "Progress in art is the development of art along an upward trajectory, the development from lower to higher, from simple to complicated, from less perfect to more perfect, which ultimately is the outcome of all social progress, and its reflection in the distinctive form of many kinds of art genres. In this sense, the progress of art is similar to innovation. Progress in art can be viewed from different perspectives: as progress throughout world art starting from its dawn to the present day, as the progress of a socio-economic formation or the art of a single country, or as progress in the oeuvre of a given artist." The article goes on to describe how progress manifests itself in different periods. In principle, this was not a renunciation of the Leninist idea of two antagonistic cultures; however, progress was no longer linked directly with realistic form, but rather signified innovation, e.g. the Gothic period led to the inception of a hitherto unprecedented polyphonic music, and the cap-

${ }^{36}$ Kangilaski, Primer, p. 310.

37 Väike esteetika leksikon, pp. 216-17; Г. Недошивин, “Марксистско-ленинская теория искусства и задачи борьбы с буржуазной эстетикой и ревизионизмом“ [G. Nedoshivin, Marksistsko-leninskaja teorija iskusstva i zadatshi borbõ s burhuasznoi estetikoi i revisionizmom / Marxist-Leninist art theory and the tasks in fighting bourgeois aesthetics and revisionism], in: Против ревизионизма в искусстве и искусствознании [Protiv revisionizma v iskusstve i iskusstvoznanii / Against revisionism in art and art history], Москва [Moskva] 1959 (Вопросы эстетики [Voprosy estetiki] 2), eds. Ю. Калашников, Г. Недошивин [J. Kalashnikov, G. Nedoshivin], Moscow 1959, pp. 9-35.

38 Kangilaski, Primer, p. 315.

39 Väike esteetika leksikon, pp. 178-179. 
italist era saw the "development of cinema in connection with technological and scientific achievements ...." 40 The watchword "innovation" found in the Lexicon also emphasised that "it does not insist on the renunciation of past aesthetic and artistic experiences as the ideologues of the proletkult did, but rather on the critical embrace of these experiences ..." And yet "Innovation must not be confused with pseudo-innovation, which is limited only to formal searches and isolates art's form from its content ... (e.g. the 'innovation' in various streams of modernism)." ${ }^{41}$ Morevoer, Nina Dmitrieva's approach, cited above a number of times, does not abandon the thesis of "two cultures," but asserts that during the capitalist era, "any sort of high art has intrinsically become anti-capitalist" (the emphasis is Dmitrieva's). Picasso is seen as embodying "high art," being "one of the contemporary era's most outstanding and controversial artists." ${ }^{\prime 2}$ In spite of the typically verbose quality of the text, and the lionisation of all of the virtues of socialism's progressivism, Dmitrieva's generalisations demonstrate a desire to break with realism-based art history and the art theory platform. Undoubtedly, this also was the aim of Jaak Kangilaski. ${ }^{43}$

Certainly, authors in the Estonian SSR took advantage of the potential of positions and narratives that had institutionally been declared legitimate in Moscow. In Tallinn, the strategy of writing also involved insinuating revisionist statements into "correct" pronouncements, concepts and assessments. Specifically, in the case of the Primer, it is clear that under the conditions of a fragile discursive pluralism, quite symbolic concepts and values from formalist Western art history were "smuggled in": concepts and values that the professional reader certainly recognised, although no names of "bourgeois" authors were mentioned. For example, Jaak Kangilaski relied on assistance in interpretation from two grand masters of the Vienna school of art history: Alois Riegl's term Kunstwollen and the Zeitgeist concept from Max Dvořák (Zeitgeist, Geistesgeschichte). In particular, the declaration of art's linear, teleological "self-development" can be considered to be an inspiration from the two. But Kangilaski's reading list obviously also included Principles of Art History by the giant of German art history, Heinrich Wölfflin ${ }^{44}$ who was declared an exemplary formalist

40 Ibidem, p. 178.

${ }^{41}$ Ibidem, pp. 166-167.

42 Основы марксистко-ленинской эстетики [Osnovõ marksistko-leninskoi estetiki], pp. 266-267.

43 The interview with Jaak Kangilaski and the author of this paper see in the cultural weekly Sirp: "Kunstiteaduse(lase) piirid ja võimalused" [Alternatives and limits of art history(historian)], Sirp 2017, 10.02.

${ }^{44}$ H. Wölfflin, Kunstgeschichtliche Grundbegriffe (1915). 
art historian in earlier official Soviet historiography. The influence of Wölfflin's discourse on Kangilaski is immediately obvious from the latter's use of the concept "linear-painterly" (linear-malerisch) ${ }^{45}$ in interpreting artworks.

On the other hand, and this was a problem for all revisionist Soviet art history, the Thaw-era discursive cocktail in art historiography led to logical contradictions. For example, something that is apparent from the general narrative in the Primer is that Jaak Kangilaski concurred with the assessment of a long-time pariah in Soviet art history, non-realistic Mannerism, declaring that it is "in conflict with true art and is fated to remain barren." ${ }^{46}$ The Primer also contains contradictions due to the automatic transposition of Voldemar Vaga's 1930s-era appraisals of architecture, which of course lacked any connection at all to Marxist-Leninist discourse; instead, they reflected stylistic-historical assessments that had developed in the $19^{\text {th }}$ century in which the stylistic unity of an architectural object ended up being valued and "eclecticism" disparaged. ${ }^{47}$ Jaak Kangilaski's sometimes romantic attitude toward the figure of the artist and the artist's creative activity also smacked of the $19^{\text {th }}$-century discourse of the artist as a genius.

Still, in spite of it all, the Primer was an attempt to modernise the Stalinist approach to art history. The most conspicuous aspect of this can be seen in the illustrations; 150 of the 279 plates are reproductions of Modernist avant-garde works from the early $20^{\text {th }}$ century on. As such, they undoubtedly embraced the new progressive movements in art.

Moving on to the more general level, there is no doubt that the engagement with the social-political reality of the day of the author of the Primer was deliberate. It apparently was supposed to function in two directions. To publish anything at all, the approach had to be ideologically "endurable": this was the price to be paid to revise past assessments regarding both the historical and, in particular, the $20^{\text {th }}$-century and contemporary avant-garde. Obviously, there is no need to mention here that none of this could have been made public without the permission of the state censorship office of GLAVLIT, the Main Directorate for Literary and Publishing Affairs. Thus, there was a need to repeat at least some of the "classical" sentences from the Marxist-Leninist discourse. Here it would be appropriate to recall an idea from the well-known Soviet culture scholar Andrei Yurtchak. Yurtchak has defined the new discursive regime in the USSR starting in the 1960s as "pragmatic." He argues that in the Late Socialist era, the form of ideological text was retained and became au-

\footnotetext{
45 Kangilaski, Primer, p. 244.

46 Ibidem, p. 238.

${ }^{47}$ Ibidem, pp. 263-264.
} 
tomated but, in parallel, values were re-interpreted based on a society that was headed toward modernisation, and was starting to look beyond its borders. ${ }^{48}$ This change revealed the growing ambivalence of Soviet culture, and thus, forces us to abandon, or at least to attach a new angle to the long established dichotomous model for viewing the entire Soviet era in terms of an official culture and its opposite, a culture of resistance. As I have hopefully succeeded in demonstrating, art history writing in the Estonian SSR was deeply engaged with the ambivalent aims of Late Socialist Soviet politics, politics that was feared and despised but that, beginning in the late 1950s, had nevertheless shown the desire to move on and change. In the Primer, the litmus test of the engagement with change was the new narrative of $20^{\text {th }}$-century art history and the illustrative material that depicted "formalist bourgeois" artworks.

\section{BIBLIOGRAPHY}

Bernstein B., "Seoses vaidlustega realismi üle" [Regarding the disputes over realism, 1-2], Kunst 1966, 3, pp. 13-22, and 1961, 1, pp. 1-14

Bernstein M., Vana kaev. Mälestusteraamat [Old Well. Book of Memoires], Tartu 2009 Dmitreva M., "The Riddle of Modernism in the Art Historical Discourse of the Thaw," in: A Socialist Realist History? Writing Art History in the Post-War Decades, eds. K. Kodres, K. Jõekalda, M. Marek, Köln, Weimar, Wien 2019, pp. 143-169

Esna O., "Kuidas puhastati Eesti raamatukogusid" [How the Estonian libraries were expurgated], Pärnu Postimees 2014, 27 th February

Hütt W., Wir und die Kunst. Eine Einführung in die Kunstbetrachtung und Kunstgeschichte, Berlin 1959

Kangilaski J., "Vaidlustest marksistlikus esteetikas" [Disputes in Marxist aesthetics], Looming 1965, 11, pp. 1707-1718

Kangilaski J., "Realismi mõiste metamorfoosid nõukogude kunstiteoorias" [Metamorphoses of the notion of realism in Soviet art theory], Kunstiteaduslikke Uurimusi / Studies on Art and Architecture 2003, 12(1-2), pp. 11-24

Kangilaski O., J. Kangilaski, Kunsti kukeaabits. Algteadmisi kunstist ja kunstiajaloost [A Basic Art Primer. Fundamental Knowledge of Art and Art History], Tallinn 1967

Каган М. С., Лекции по марксистско-ленинской эстетике, часть II [M. S. Kagan, Lekcii po marksistsko-leninskoy estetikie, II], Leningrad 1964

Kodres K., "Scientific Baroque - for Everyone. Constructing and Conveying an Art Epoch during the Stalinist Period in the Soviet Union and in Soviet Estonia," in: $\mathrm{Ba}$ roque for a Wide Public: Popular Media and Their Constructions of the Epoch on Both Sides of the Iron Curtain, eds. M. Marek, E. Pluhařovà-Grigienéenè, Journal of Art Historiography. Special Issue 2016, 15 [https://arthistoriography.wordpress. com/15-dec16/], pp. 1-25

48 A. Yurchak, "Soviet Hegemony of Form: Everything was Forever, Until It Was No More," Comparative Studies in Society and History 2003, 45(3), pp. 480-481. 
Kodres K., K. Jõekalda, "Introduction to Socialist Art History: On Formulating the Soviet Canon," in: A Socialist Realist History? Writing Art History in the PostWar Decades, eds. K. Kodres, K. Jõekalda, M. Marek, Köln, Weimar, Wien 2019, pp. 11-35

"Kunstiteaduse(lase) piirid ja võimalused" [Alternatives and limits of art history(historian)], Sirp 2017, 10.02, p. 5

Лармин О. В., Художественный метод и стиль [О. V. Larmin, Hudozhestvennõi metod i stilj], Moscow 1964

Аифшиц М., Вопросы искусства и философии [M. Lifshits, Voprosõ iskusstva i filosofii], Moscow 1935

Lukacs G., Essays über Realismus, Berlin 1948

Недошивин Г., “Марксистско-ленинская теория искусства и задачи борьбы с буржуазной эстетикой и ревизионизмом“ [G. Nedoshivin, Marksistsko-leninskaja teorija iskusstva i zadatshi borbõ s burhuasznoi estetikoi i revisionizmom / Marxist-Leninist art theory and the tasks in fighting bourgeois aesthetics and revisionism], in: Против ревизионизма в искусстве и искусствознании [Рrоtiv revisionizma $\mathrm{v}$ iskusstve $\mathrm{i}$ iskusstvoznanii / Against revisionism in art and art history], Москва [Moskva] 1959 (Вопросы эстетики [Voprosy estetiki] 2), eds. Ю. Калашников, Г. Недошивин [Yu. Kalashnikov, G. Nedoshivin], Moscow 1959, pp. 9-35

Основы марксистко-ленинской эстетики [Osnovõ marksistko-leninskoi estetiki], Moscow 1960; in Estonian: Marksistlik-leninliku esteetika alused, Tallinn 1961

Штамбок А., Против идеалистического исктолкования развития искусства [A. Shtambok, Protiv idealistitsheskovo isktolkovanija razvitija iskusstva / Against the idealistic interpretation of the development of art], Искусство [Isskustvo] 1950, 5, pp. 55-65

Väike esteetika leksikon [Small Lexicon of Aesthetics], Tallinn1965

Yurchak A., "Soviet Hegemony of Form: Everything was Forever, Until It Was No More," Comparative Studies in Society and History 2003, 45(3), pp. 480-510

\section{Krista Kodres}

Estonian Academy of Arts, Tallinn

TOWARD A NEW CONCEPT OF PROGRESSIVE ART:

ART HISTORY IN THE SERVICE OF MODERNISATION

IN THE LATE SOCIALIST PERIOD. AN ESTONIAN CASE

\section{Summary}

The paper deals with renewal of socialist art history in the Post-Stalinist period in Soviet Union. The modernisation of art history is discussed based on the example of the Estonian Soviet Socialist Republic (Estonian SSR), where art historians were forced to accept the Soviets' centrally constructed Marxist-Leninist aesthetic and approach to art and art history. In the art context, the idea of progressiveness began to be reconsidered. 
In previous discourse, progress was linked with the "realist" artistic method that sprang from a progressive social order. Now, however, art historians found new arguments for accepting different cultures of form, both historical and contemporary, and often these arguments were "discovered" in Marxism itself. As a result, from the middle of 1950's Soviet art historians fell into two camps in interpreting Realism: the dogmatic and revisionist, and the latter was embraced in Estonia. In 1967, a work was published by the accomplished artist Ott Kangilaski and his nephew, the art historian Jaak Kangilaski: the Kunsti kukeaabits - Basic Art Primer - subtitled "Fundamental Knowledge of Art and Art History." In its 200 pages, Jaak Kangilaski's Primer laid out the art history of the world. Kangilaski also chimed in, publishing an article in 1965 entitled "Disputes in Marxist Aesthetics" in the leading Estonian SSR literary journal Looming (Creation). In this paper the Art Primer is under scrutiny and the deviations and shifts in Kangilaski's approach from the existing socialist art history canon are introduced. For Kangilaski the defining element of art was not the economic base but the "Zeitgeist," the spirit of the era, which, as he wrote, "does not mean anything mysterious or supernatural but is simply the sum of the social views that objectively existed and exist in each phase of the development of humankind." Thus, he openly united the "hostile classes" of the social formations and laid a foundation for the rise of common art characteristics, denoted by the term "style." As is evidenced by various passages in the text, art transforms pursuant to the "will-to-art" (Kunstwollen) characteristic of the entire human society. Thus, under conditions of a fragile discursive pluralism in Soviet Union, quite symbolic concepts and values from formalist Western art history were "smuggled in": concepts and values that the professional reader certainly recognised, although no names of "bourgeois" authors were mentioned. Kangilaski relied on assistance in interpretation from two grand masters of the Vienna school of art history: Alois Riegl's term Kunstwollen and the Zeitgeist concept from Max Dvořák (Zeitgeist, Geistesgeschichte). In particular, the declaration of art's linear, teleological "self-development" can be considered to be inspiration from the two. But Kangilaski's reading list obviously also included Principles of Art History by Heinrich Wölfflin, who was declared an exemplary formalist art historian in earlier official Soviet historiography. Thaw-era discursive cocktail in art historiography sometimes led Kangilaski to logical contradictions. In spite of it, the Primer was an attempt to modernise the Stalinist approach to art history. In the Primer, the litmus test of the engagement with change was the new narrative of $20^{\text {th }}$ century art history and the illustrative material that depicted "formalist bourgeois" artworks; 150 of the 279 plates are reproductions of Modernist avant-garde works from the early $20^{\text {th }}$ century on. Put into the wider context, one can claim that art history writing in the Estonian SSR was deeply engaged with the ambivalent aims of Late Socialist Soviet politics, politics that was feared and despised but that, beginning in the late 1950s, nevertheless had shown the desire to move on and change.

Keywords:

Socialist art history and historiography, Soviet studies, Thaw era and modernisation, centre (Moscow) and periphery (Estonian SSR) relations, art and ideology, progressiveness in art 